\title{
Increasing maize silage yields in Taranaki
}

R. J. DENSLEY, D.J.W. MCDONALD, D.W. DENSLEY and D.B. MILLER Genetic Technologies Ltd, P.O. Box 105 303, Auckland rdensley@genetic.co.nz

\begin{abstract}
Improved productivity and utilisation of forages will be central to maintaining business viability on high value Taranaki dairy land. Data from 712 plots in 119 trials planted over ten years in Taranaki was analysed to determine average yields and the impact of planting date on yield. Six rural contractors who plant approx. $90 \%$ of maize in Taranaki were surveyed to determine the perceived factors most limiting maize yields in the Taranaki. The overall average Taranaki maize silage dry matter (DM) yield of all hybrids from the trialling program over the past ten years was $20.5 \mathrm{t} \mathrm{DM} / \mathrm{ha}$ and the average harvest DM content was $33.8 \%$. Currently commercially available hybrids yielded an average of $20 \mathrm{t} \mathrm{DM} / \mathrm{ha}$. Average maize silage yield/yr varied from a high of $22 \mathrm{t} \mathrm{DM} /$ ha in 1999 to a low of $18.3 \mathrm{t} \mathrm{DM} /$ ha in 2004.

Planting between the 15th and 24th October gave the greatest crop yield. Paddock selection seemed to be driven by the need for pasture renovation rather than paddocks being selected because they provide an ideal growing environment for maize. Contractors suggested shelter was a key consideration for increasing yields.

Keywords: cropping, maize sila ge, Taranaki
\end{abstract}

\section{Introduction}

From 1993 to 2004 the median dairy farm sale price/ha for Taranaki dairy farms has increased by $81 \%$ from $\$ 13424 /$ ha to $\$ 24353 /$ ha (Quotable Value 2005). During the same period the payout has increased from $\$ 3.39 / \mathrm{kg}$ milksolids (MS) to $\$ 4.25 / \mathrm{kg}$ MS (+25\%) and production has increased from $763 \mathrm{~kg} \mathrm{MS} / \mathrm{ha}$ to $950 \mathrm{~kg}$ $\mathrm{MS} / \mathrm{ha}(+24 \%)$. As a result income/ha has risen from $\$ 2587$ to $\$ 4038(+56 \%)$ over the same period.

To maintain the viability of their businesses, Taranaki farmers must continue to increase production and productivity/ha. This will largely be driven by increasing the amount of DM grown and harvested/ha.

Large improvements in the genetic yield potential of maize hybrids have occurred in the last 70 years. In a study conducted in Wisconsin, USA during the 19971998 season, maize hybrids that were commercially released during the period 1900-1997 were planted sideby-side at three locations and yield and quality characteristics were compared. Since 1930, maize silage DM yield has increased at the rate of 128 to $164 \mathrm{~kg} \mathrm{DM} /$ ha/yr (Lauer et al. 2001).

The biological maximum for maize grain yield was calculated to be $31.5 \mathrm{t} /$ ha (Tollenaar 1985). This translates to a maize silage yield of approximately $56.7 \mathrm{t}$ $\mathrm{DM} / \mathrm{ha}$ and is equivalent to the actual yield achieved by Francis Childs, winner of the 2002 USA National Corn Growers Association Contest (Zinkand 2002). Trials conducted on New Zealand dairy farms show average maize silage yields in the range of 20-25 t DM/ha (Densley et al. 2001).

Most of the costs associated with growing and harvesting maize silage are fixed. Therefore the crop yield is the single variable that has the largest impact on maize silage cost. Assuming a total maize silage cost (spray out pasture to maize silage feed-out) of $\$ 3347 /$ ha (Genetic Technologies Ltd 2005), increasing maize silage DM yield from $20 \mathrm{t} / \mathrm{ha}$ to $21 \mathrm{t} / \mathrm{h}$ a would decrease the cost $/ \mathrm{kg}$ DM eaten by 0.8 cents.

The aim of this paper is to quantify maize silage yields in Taranaki and to identify the factors that influence yield. This paper identifies possible management strategies for increasing maize yield and develops a best practice protocol for growing maize silage in Taranaki.

\section{Materials and methods Field testing}

A range of experimental and commercially available maize silage hybrids were planted in 712 plots at 119 Taranaki sites during spring of the years 1995 to 2004. The hybrids planted in each trial were of a similar maturity. Not all hybrids were represented at each site and not all hybrids were represented in each year. The trials were planted in commercial maize silage paddocks on either dairy farms or maize silage cropping farms or at the Pioneer $\AA$ brand Maize Research Stations located at Waverley or the Taranaki Farmers Demonstration site at Nor manby. On-farm locations ranged from Waverley in the south to Tikorangi in the north.

Trials were planted with $76.2 \mathrm{~cm}$ row commercial maize precison planters. Each trial contained 5-12 hybrids of similar comparative relative maturity (CRM) with each hybrid strip consisting of four or six rows depending on the planter width. Hybrids were randomly allocated to strips. Each hybrid was planted once. Each trial was planted in the middle of a commercial crop which provided guard rows on each side.

Granular insecticide or insecticide treated seed was used as per the industry norm for the season. The planting population was generally in the range of 100000 to 120000 seeds/ha. 
Table 1 Average maize silage hybrid yields (t DM/ha) in Taranaki (1999-2005).

\begin{tabular}{|c|c|c|c|c|c|c|}
\hline Hybrid & CRM & $\begin{array}{c}\text { Number of } \\
\text { years tested }\end{array}$ & $\begin{array}{l}\text { Total number } \\
\text { of sites }\end{array}$ & $\begin{array}{l}\text { Days from } \\
\text { planting to harvest }\end{array}$ & $\begin{array}{l}\text { Average yield } \\
\text { (t DM/ha) }\end{array}$ & $\begin{array}{l}\text { Yield range* } \\
\text { (t DM/ha) }\end{array}$ \\
\hline Pioneer $^{\circledR} \quad 39 \mathrm{~K} 38$ & 87 & 5 & 24 & 165 & 19.5 & $15.3-23.0$ \\
\hline Pioneer $38 \mathrm{G} 43$ & 87 & 8 & 49 & 162 & 20.3 & $17.0-23.6$ \\
\hline Pioneer $^{\circledast} \quad 38 \mathrm{~F} 70$ & 93 & 8 & 65 & 155 & 20.2 & $17.5-23.0$ \\
\hline Pioneer $^{\circledR}$ 38P05 & 94 & 7 & 46 & 155 & 20.3 & $17.4-23.3$ \\
\hline Pioneer $^{\circledR} 36 \mathrm{H} 36$ & 100 & 6 & 42 & 160 & 21.3 & $18.6-24.0$ \\
\hline
\end{tabular}

\section{Yield measurements}

Silage harvest took place when the hybrids were visually assessed (using kernel milk-line score) to be between 30-38\% whole plant DM content.

A uniform section of the crop was selected and the plants from three $5.3 \mathrm{~m}$ strips of one of the middle two rows of each hybrid were hand cut at $15 \mathrm{~cm}$ above ground level (standard mechanical harvesting height) and weighed. Harvest population was measured in most trials from 1998 onwards. A total of eighteen plants (six/ strip) were chopped to provide a sample for DM determination. A $1 \mathrm{~kg}$ sample of chopped whole plant maize was collected and dried at $62^{\circ} \mathrm{C}$ until constant weight. DM yield was determined for each plot (three 5.3 m lengths).

\section{Data analysis}

The average DM yield/yr across all sites and all hybrids and the average DM yield across all hybrids and all years (a total of 712 plots) were calculated. The average DM yield and days from planting to harvest of five current commercially available hybrids (Pioneer ${ }^{\circledR}$ brand 39 K38, $38 \mathrm{G} 43$, 38F70, 38P05 and 36H36) for all sites and all years of testing were calculated.

Average maize silage DM yield by planting date was determined for 10-day periods from 5 th October to 27 th November.

\section{Survey method}

A survey of the Taranaki a gricultural contractors $(n=6)$ who plant and harvest maize silage for ten or more clients was conducted. Contractors were asked to rank the key factors that limited maize silage yield in Taranaki. They were also asked to provide information on current practice for paddock selection, time of planting, planting population and fertiliser and herbicide timing and application rates.

\section{Results and discussion Strip trial results}

The overall average Taranaki maize silage
DM yield of all hybrids from the trialling program over the past ten years ( 712 plots) was $20.5 \mathrm{t} \mathrm{DM} / \mathrm{ha}$ and the average harvest DM content was $33.8 \%$. The average harvest population (599 plots) was 103000 plants/ha. Currently commercially available hybrids yielded an avera ge of $20.3 \mathrm{t} \mathrm{DM} /$ ha (Table 1).

Average maize silage yield/yr varied from a high of $22.0 \mathrm{t} \mathrm{DM} /$ ha in 1999 to a low of $18.3 \mathrm{t} \mathrm{DM} /$ ha in 2004 . Maize silage yields of more than $26 \mathrm{t} \mathrm{DM} /$ ha were recorded in ten trial strips and more than $25 \mathrm{t} \mathrm{DM} /$ ha in 28 trial strips indicating that higher yields can be achieved.

\section{Planting date}

The ten-year average trial data showed that maize silage yields were the highest for crops that were planted in the 10 day period October 15th - October 24th. Crops planted after the 13th November tended to yield less than those crops planted before this date (Table 2) although data were collected from only a few $(n=29)$ late planted sites.

Maize silage planting date trials conducted in Wisconsin showed a relationship between maize silage hybrid planting date and DM yield, however, the optimum planting date varied by district but remained at $95 \%$ of maximum yields for 3-4 weeks after the optimum planting date (Darby \& Lauer 2002). While the Taranaki results should be viewed with caution since the database contains trials conducted over many seasons and districts, we suggest growers should aim to plant before midNovember.

Table 2 Average maize silage hybrid yields (t DM/ha) by planting period in Taranaki (1999-2005).

\begin{tabular}{lcc}
\hline Planting period & $\begin{array}{c}\text { Total number } \\
\text { of sites }\end{array}$ & Average yield \\
\hline October 5-October 14 & 53 & 20.0 \\
October 15-October 24 & 250 & 21.2 \\
October 25-November 3 & 187 & 20.2 \\
November 4-November 13 & 186 & 20.0 \\
November 14-November 23 & 21 & 19.0 \\
November 24-November 27 & 8 & 19.2 \\
\hline
\end{tabular}


Table 3 Growing degree unit accumulation for three Taranaki weather sites (1 October 2004 - 30 April 2005).

\begin{tabular}{lccc}
\hline & Stratford (E94334) & Hawera (E94622) & New Plymouth (C94012) \\
\hline October & 79 & 91 & 104 \\
November & 122 & 133 & 143 \\
December & 118 & 130 & 140 \\
January & 191 & 199 & 222 \\
February & 218 & 227 & 265 \\
March & 173 & 193 & 235 \\
April & 107 & 114 & 142 \\
Total (1 October - 20 April) & 1008 & 1087 & 1251 \\
\hline
\end{tabular}

a Weather station reference number. Data source NIWA.

\section{Current maize silage practice}

We surveyed contractors because they have involvement in all steps of the cropping process for a large number of crops each season and can differentiate between low and high yielding crops. The contractors surveyed planted and harvested around $90 \%$ of the maize silage grown in Taranaki. However, the survey results reported in this paper should be taken as indications only since the sample size was small $(\mathrm{n}=6)$.

The survey revealed that few farmers chose the best paddock to grow a maize silage crop. Contractors said that about half of their farmer clients were growing maize silage in the same paddock annually (often on a run-off) and the other half chose a poor or problem paddock that needed regrassing.

Crops on run-offs were often planted after a grass silage crop had been harvested from the paddock. For on-farm crops, time of planting was often determined by when the farmer had enough grass to take a paddock out of the grazing round. Average seeding rates were estimated by the contractors to be between 105000 and 120000 seeds/ha.

The base fertiliser product and rate varied greatly but often included $50 \%$ potassic superphosphate containing phosphorus (P) and potassium (K) (NPK 0:4.5:25) at $500 \mathrm{~kg} / \mathrm{ha}$ and magnesium $(100 \mathrm{~kg} / \mathrm{ha})$. Most farmers were using Osflo ${ }^{\circledR}$ chicken manure fertiliser (3.3:1.5:1.7) at 2.5-5.0 t/ha.

A starter fertiliser containing NPK (12:10:10) was typically applied at the rate of $250-300 \mathrm{~kg} / \mathrm{ha}$. Most of the contractors felt that the majority of crops had adequate starter fertiliser $(\mathrm{n}=4)$ although one contractor felt that starter fertiliser rates were too low and one commented that up to $25 \%$ of his clients applied additional nitrogen $(100-200 \mathrm{~kg} \mathrm{~N} / \mathrm{ha})$ in the base fertiliser instead of using starter fertiliser.

Contractors agreed that the pre-emergent herbicide (e.g. Atrazine $31 /$ ha plus Roustabout $31 /$ ha) was g enerally applied at the correct time but several commented that the herbicide activity became ineffective before the crop reached inter-row cover and there was a need for an additional post-emergent herbicide to control weeds such as summer grass (Digitaria sanguinalis), couch (Agropyron repens), fat hen (Chenopodium album) and inkweed (Phytolacca octandra). This phenomenon is probably a function of low daily spring heat unit accumulation (Table 3 ) causing low maize growth and delaying the time for maize canopy cover.

Side-dress $\mathrm{N}$ was usually applied at the 5-leaf stage (V5) at a rate of $100-200 \mathrm{~kg} \mathrm{~N} / \mathrm{ha}$. Three contractors believed that the timing and rate of $\mathrm{N}$ fertiliser application were ideal while two felt that too little $\mathrm{N}$ was applied and the timing was too late for maximum plant response.

\section{Limitations to maize silage yield}

All of the contractors felt that a lack of heat units or wind/lack of shelter was the primary limitation to maize silage yield in Taranaki. Poor weed control, low soil fertility and low established plant population were also cited as reasons for low crop yield.

Maize plant maturity is influenced largely by heat accumulation which can be calculated as Growing Degree Units (GDU) (Aldrich et al. 1986):

$$
\text { GDU }=((\operatorname{Tmax}+\mathrm{Tmin}) / 2)-10^{\circ} \mathrm{C}
$$

$\operatorname{Tmax}=$ maximum daily temperature (upper limit is $30^{\circ} \mathrm{C}$ ) Tmin $=$ minimum daily temperature (lower limit is $\left.10^{\circ} \mathrm{C}\right)$

Later maturing hybrids (higher CRM) require more GDUs from planting to harvest than earlier maturing hybrids, however, their yield potential is higher. An analysis of the weather data for Taranaki reveals that there is a wide range in the maize heat units by district (Table 3). In cooler districts (e.g. Stratford) it is critical that growers plant early-maturing hybrids early in the season to ensure that they receive enough heat to reach maturity in time for autumn regrassing.

Taranaki is often subjected to periods of wind. The mean wind speed at New Plymouth airport (1995-2004) was $18 \mathrm{~km} / \mathrm{h}$ (Stuart Burgess, NIWA pers. comm.). Wind affects maize crops by lowering the ambient 
temperature, decreasing soil moisture levels, and, in extreme cases, by shredding leaves reducing the plants ability to photosynthesise and grow (Zhang \& Brandle 1996). Taranaki farmers growing maize silage on farm should consider choosing a paddock which is sheltered from the prevailing wind. For those who grow crops on the same land area, planting shelter may increase maize silage yields in the long term.

\section{Planting population}

Modern maize silage hybrids have improved stress tolerance (Tollenaar \& Lee 2002) making them more adaptable to planting at higher populations (Paszkiewicz \& Butzen 2001). Maize silage plant population trials conducted at a number of locations, including Taranaki, have shown that, lifting established populations to 115000 - 130000 plants/ha is profitable, despite increased seed costs, for dairy farmers growing and feeding maize silage (Densley et al. 2003).

Taranaki growers should follow the recommended trend and increase seeding populations of maize to maximise yields.

\section{Weed control}

Since weeds compete with the maize plants for sunlight, water and nutrients, poor weed control can reduce maize growth. A study conducted in the USA showed that season-long weed interference could decrease maize silage DM yield by 70 to $75 \%$ and calculated milk yield by 75 to $80 \%$ when compared to weed-free maize (Cox et al. 2005). There are a wide range of herbicide options to control weeds in maize crops (NZ Agrichemical Manual 2004). Growers should monitor their crops until leaf cover of inter-row spaces occurs and apply additional herbicide as required.

\section{Fertiliser application}

Maize crops must be provided adequate nutrients if they are to reach their yield potential. A $20 \mathrm{t} \mathrm{DM} /$ ha maize silage crop has a requirement for $180 \mathrm{~kg} \mathrm{~N} / \mathrm{ha}, 40 \mathrm{~kg}$ $\mathrm{P} / \mathrm{ha}$ and $120 \mathrm{~kg} \mathrm{~K} / \mathrm{ha}$ (Densley 2002). Obtaining a representative soil test in the late winter/early spring should be the first step in determining a maize silage fertiliser programme. Paddocks out of permanent pasture usually require less nitrogen that those which have been continually cropped.

Studies conducted over several decades have identified the benefits of using starter fertiliser at planting (Gaspar 2002). Typically, benefits of starter fertiliser include increased grain yield, improved root growth, rapid early season growth and earlier canopy closure to reduce late weed development. A 3-year study at the University of Wisconsin evaluated maize yield response to starter fertiliser at 100 on-farm sites that generally had excessively high soil $\mathrm{P}$ and $\mathrm{K}$ levels (Bund y \& Andraski 1999). The study showed that fields with high $P$ and $K$ were still responsive to starter fertiliser applications and that environments with cool soil conditions were more likely to have positive responses to starter fertiliser.

Ear shoot initiation occurs just before the V5 (5 true leaves) stage and this determines the potential number of cobs per plant (Ritchie et al. 1993). The maximum number of rows of kernels develops by approximately V7 (range of V5-V8). The number of potential kernels/row (cob length) is determined between V12 through to just prior to pollination and fertilisation of the yield potential occurs at flowering (Theisen 2005). Growers should match the rate and timing of $\mathrm{N}$ application with likely plant demand to ensure that maximum yield potential is both set and achieved.

\section{Conclusion}

Average Tar anaki strip trial yields of commercial maize silage hybrids are in the range of 19-21 t DM/ha. Yields of up to $26 \mathrm{tDM} /$ ha have been achieved.

This paper identifies that time of planting, shelter, plant population, starter fertiliser, weed control and $\mathrm{N}$ application may be limiting maize silage yields in Taranaki. Additional, more controlled experiments are necessary to identify the impact of these variables on yield.

\section{ACKNOWLEDGEMENTS}

The authors would like to thank the Pioneer field technicians who provided substantial technical assistance and Brian Meece, Pioneer Hi-Bred International, for assistance with data analysis.

\section{REFERENCES}

Aldrich, S.R.; Scott, W.O.; Hoeft, R.G. 1986. Modern com production (third edition). A \& L Publications, Champaign, Illinois, USA. .

Bundy, L.G.; Andraski, T.W. 1999. Site specific factors affecting corn response to star ter fertilizer. Joumal of Production Agriculture 12:676-670.

Cox, W.J.; Hahn, R.R.; Stachowski, P.J.; Cherney, J.H. 2005. Weed interference and glyphosate timing affect com forage yield and quality. Agronomy Journal 97: 847-853.

Darby H.M.; Lauer, J.G. 2002. Planting date and hybrid influence on com forage yield and quality. Agronomy Journal 94: 281-289.

Densley, D.W. 2002. Fertiliser recommendations for forages using soil tests and an excel spreadsheet. In: Dairy farm soil management. (Eds L D Currie and P Loganathan). Occasional report No. 15. Fertilizer and Lime Research Centre, Massey University, Palmerston North. pp 389-395.

Densley, R.J; Brenton-Rule, R.J; Austin, G.M; Densley, 
D.W; Tsimba, R. 2003. The effect of increasing plant population on maize silage yield and quality. Proceedings of the New Zealand Grassland Association 65: 117-122.

Densley, R.; Miller, D.; Kolver, E.S. 2001:Breaking the feed barrier using maize silage. Proceedings of the New Zealand Grasslands Association 63: 289-293.

Gaspar, P.E. 2002. Review of recent starter fertiliser research. pp 1-5. Pioneer Hi-Bred International. Des Moines. Iowa, USA.

Genetic Technologies Ltd. 2005. Farming for more success. Pioneer ${ }^{\circledR}$ brand forage products for 2005 2006. Auckland. p 11.

Lauer, J.G.; Coors, J.G.; Flannery, P.J. 2001. Forage yield and quality of corn cultivars developed in different eras. Crop Science 41: 1449 - 1455.

New Zealand Agrichemical Manual. 2004. Ed. Young, S. Agrimedia Ltd. Christchurch.

Paskiewicz, S.; Butzen, S. 2001. Corn hybrid responses to plant population. Pioneer Crop Insights Volume 11. No 6. Pioneer Hi-Bred International Inc, Iowa, USA. Quotable Value 2005. Median sale price (sale price net plus chattels) for dairy farms for two specific regions. Customised report. Quotable Value, Wellington.

Ritchie, S.W.; Hanway, J.J.; Benson, G.O. 1993. How a corn plant develops. Special Report No 48. Iowa State University, Iowa, USA.

Thiesen, R. 2005. Walking Your Fields Newsletter. June 13th 2005. Pioneer Hi-Bred International, Iowa, USA.

Tollenaar, M. 1985. What is the current upper limit of corn productivity? $7 \mathrm{pp}$. In: Proceedings of the Conference on Physiology, Biochemistry and Chemistry Associated with Maximum Yield Corn. Foundation for Agronomic Research and Potash Phosphate Institute, St Louis, Missouri, USA.

Tollenaar M.; Lee, E.A. 2002. Yield potential, yield stability and stress tolerance in maize. Field Crops Research 75: 161-169.

Zhang, H.; Brandle, J.R. 1996. Windbreak effect on biomass and grain mass accumulation of corn: a modeling approach. Agronomy Journal 88: 607-613.

Zinkand, D. 2002. Childs keeps his crown. Iowa Farmer Today. December 28th. p 20. 